\title{
KARAKTER MORFOLOGI, HERITABILITAS, DAN INDEKS SELEKSI TERBOBOTI BEBERAPA GENERASI F1 MELON (Cucumis melo L.)
}

\section{MORPHOLOGICAL CHARACTER, HERITABILITY, AND SELECTION INDEX OF SOME F $_{1}$ GENERATIONS OF MELON (Cucumis melo L.)}

\author{
Achmad Amzeri ${ }^{*}$, Kaswan Badami, Syaiful Khoiri, Ahmad Syaiful Umam, Nasirul Wahid \\ dan Siti Nurlaella
}

Program Studi Agroteknologi, Fakultas Pertanian, Universitas Trunojoyo Madura

Jl. Raya Telang PO BOX 2 Kamal Bangkalan Madura

Korespondensi : aamzeri@gmail.com

Diterima : 27 November 2019 / Disetujui : 14 Juli 2020

\begin{abstract}
ABSTRAK
Perakitan varietas melon hibrida dengan karakter-karaker unggul merupakan suatu upaya untuk memenuhi kebutuhan benih melon dalam negeri dan mengurangi ketergantungan impor benih melon dari luar negeri. Tujuan penelitian ini adalah untuk mengevaluasi penampilan fenotipik 24 genotip tanaman melon hibrida $\left(F_{1}\right)$. Penelitian ini dilakukan di Kebun Percobaan Agroteknologi Fakultas Pertanian Universitas Trunojoyo Madura pada bulan Februari sampai Mei 2019. Bahan yang digunakan adalah 24 genotip melon hibrida $\left(F_{1}\right)$ hasil persilangan di antara galur-galur melon. Penelitian ini menggunakan Rancangan Acak Kelompok dengan satu perlakuan yaitu genotip dan diulang sebanyak 3 kali. Analisis data menggunakan analisis varians (Anova) yang dilanjutkan dengan uji Duncan pada taraf $5 \%$. Nilai heritabilitas dalam arti luas dihitung menggunakan taksiran nilai kuadrat tengah pada analisis varians. Seleksi indeks digunakan untuk mendapatkan kandidat varietas tanaman melon hibrida. Hasil penelitian menunjukkan bahwa 24 tanaman melon hibrida $\left(F_{1}\right)$ yang diuji memiliki perbedaan penampilan pada karakter umur berbunga, panjang buah, diameter buah, tebal daging buah, kadar gula, jumlah biji per buah, bobot buah pertanaman dan produksi per hektar. Nilai heritabilitas dalam arti luas tanaman melon hibrida $\left(F_{1}\right)$ pada karakter yang dievaluasi berkisar antara 0,15-0,71. Hasil nilai seleksi indeks terboboti menunjukkan bahwa terdapat dua calon varietas tanaman melon hibrida yang memiliki seleksi indeks tertinggi yaitu $\mathrm{G}_{4}$ dan $\mathrm{G}_{5}$.
\end{abstract}

Kata kunci : heritabilitas, melon hibrida, penampilan fenotipik, seleksi indeks

\section{ABSTRACT}

Assembling hybrid melon varieties with superior characters is an effort to meet the ne eds of domestic melon seeds and reduce dependence on imported melon seeds. The purpose of this study was to evaluate the phenotypic appearance of 24 genotypes of hybrid melon plants $\left(F_{1}\right)$. This research was conducted at the Agrotechnology Experimental Field at Faculty of Agriculture, Universitas Trunojoyo Madura from February to May 2019. The materials used

Cyte this as: Amzeri, A., Badami, K., Khoiri, S., Umam, A, S., Wahid, N. \& Nurlaella, S. (2020). Karakter morfologi, heritabilitas dan indeks seleksi terboboti beberapa generasi F1 Melon (Cucumis melo L.). Jumal Agro, 7(1), 42-51. https://doi.org/10.15575/6244 
were 24 genotypes of hybrid melon resulting from melon lines crossing. The experimental design used was randomized block design with three replications. The data analysis used analysis of variance (ANOVA) followed by the Duncan test at $5 \%$. Broad sense heritability was obtained from the estimated middle squared value of Anova. Index selection was applied to search candidate varieties of hybrid melon plants. The results showed that 24 hybrid melon plants $\left(F_{1}\right)$ tested had different appearance on the characters of flowering age, fruits length, fruits diameter, thick of fruit flesh, sugar content, number of seeds perfruit, fruit weight and production per hectare. Broad sense heritability on the characters evaluated ranged from 0.15 - 0.71. The results of the selection index value indicated there are two candidates of hybrid melon varieties that have the highest index selection i.e. $G_{4}$ and $G_{5}$.

Keywords: heritability, index selection, melon hybrid, phenotypic appearance

\section{PENDAHULUAN}

Melon merupakan salah satu komoditas hortikultura penting di Indonesia, di mana produksi melon mengalami peningkatan pada beberapa tahun terakhir. Menurut Badan Pusat Statistik (2017) bahwa produksi melon di Indonesia pada tahun 2013 sebesar $125.207 \mathrm{t}$, tahun 2014 mencapai $150.365 \mathrm{t}$ dan pada tahun 2015 sebesar $137.887 \mathrm{t}$ dengan luas panen 8.185 hektar. Produksi tersebut hanya memenuhi kebutuhan pasar nasional sebesar $40 \%$.

Luas areal penanaman tanaman melon yang cukup besar di Indonesia menyebabkan kebutuhan benih melon di Indonesia sangat besar. Pada tahun 2017, kebutuhan benih melon sekitar 4,1 t dan produksi benih melon dalam negeri 2,5-3 t per tahun (Badan Pusat Statistik (BPS), 2017). Produksi benih melon di Indonesia yang belum memenuhi kebutuhan dalam negeri, menyebabkan Indonesia mengimpor benih dari luar negeri untuk memenuhi kebutuhan tersebut (Ishak \& Daryono, 2018). Perakitan varietas melon hibrida dengan karakter-karaker unggul merupakan suatu upaya untuk memenuhi kebutuhan benih melon dalam negeri dan mengurangi ketergantungan impor benih melon dari luar negeri.

Perakitan varietas unggul dilakukan dengan teknik hibridisasi yang dilanjutkan dengan seleksi tanaman. Hibridisasi merupakan teknik yang sangat efektif untuk mendapat tanaman dengan karakter-karakter yang dikehendaki (Amzeri, 2015; Golabadi et al., 2015; Olfati et al., 2012). Hibridisasi dapat dilakukan diantara galur-galur yang mempunyai potensi Daya Gabung Khusus tinggi (heterosis) untuk dijadikan varietas hibrida (Hartati \& Sudarsono, 2016).

Hasil hibridisasi $\left(F_{1}\right)$ yang mempunyai nilai heterosis tinggi dapat digunakan sebagai kandidat varietas melon hibrida yang mempunyai karakter-karakter unggul. Untuk mengetahui potensi karakterkarakter yang diinginkan, perlu dilakukan pengujian pendahuluan pada tanaman melon hasil hibridisasi $\left(F_{1}\right)$.

Penelitian ini bertujuan untuk mengevaluasi karakter morfologi, hertitabilitas dan mendapatkan kandidat tanaman melon hibrida berdasarkan indeks seleksi terboboti dengan karakter-karakter yang diinginkan. 


\section{BAHAN DAN METODE}

Penelitian ini dilakukan di Kebun Percobaan Agroteknologi Fakultas Pertanian Universitas Trunojoyo Madura pada bulan Februari - Mei 2019. Lokasi penelitian berada pada ketinggian $4 \mathrm{mdpl}$ dengan jenis tanah grumosol.

Bahan tanam yang digunakan adalah 24 genotip benih melon hibrida $\left(F_{1}\right)$ hasil persilangan diantara galur-galur melon (Tabel 1), pupuk kandang kotoran sapi, furadan 3G, herbisida, fungisida (klorotalonil 75\%, propineb $70 \%$ ), insektisida (deltametrin $25 \mathrm{~g} / \mathrm{l}$ ), Gandasil D, perekat Agristik, pupuk ZA, NPK 16:16:16, $\mathrm{SP}-36, \mathrm{KCl}$ dan $\mathrm{KNO}_{3}$.

Tabel 1. 24 genotip melon hibrida $\left(F_{1}\right)$

\begin{tabular}{|c|c|c|}
\hline No & Genotip & Hibridisasi \\
\hline 1 & $\mathrm{G}_{1}$ & q H.4.1.1 x ô L.5.1.1 \\
\hline 2 & $\mathrm{G}_{2}$ & q H.4.1.1 x $\widehat{o}$ L.1.1.1 \\
\hline 3 & $\mathrm{G}_{3}$ & q H.4.1.1 x §̂ L.2.1.1 \\
\hline 4 & $\mathrm{G}_{4}$ & 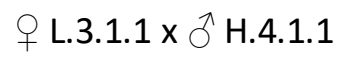 \\
\hline 5 & $\mathrm{G}_{5}$ & q L.1.1.1 x ठ̂ H.4.1.1 \\
\hline 6 & $\mathrm{G}_{6}$ & q D.5.1.1 x ठ̂̉ L.3.1.1 \\
\hline 7 & $\mathrm{G}_{7}$ & 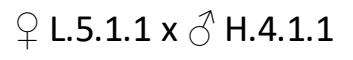 \\
\hline 8 & $\mathrm{G}_{8}$ & o L.6.1.1 x ô LL.1.1.1 \\
\hline 9 & $\mathrm{G}_{9}$ & o L.4.1.1 x ô LL.1.1.1 \\
\hline 10 & $\mathrm{G}_{10}$ & q LL.1.1.1 x ô L.3.1.1 \\
\hline 11 & $\mathrm{G}_{11}$ & of D.5.1.1 x ڤ̂ L.6.1.1 \\
\hline 12 & $\mathrm{G}_{12}$ & q D.5.1.1 x ठ̂̉ L.5.1.1 \\
\hline 13 & $\mathrm{G}_{13}$ & 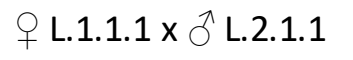 \\
\hline 14 & $\mathrm{G}_{14}$ & q L.1.1.1 x ổ L.3.1.1 \\
\hline 15 & $\mathrm{G}_{15}$ & q L.1.1.1 x $\overbrace{}^{\Uparrow}$ L.4.1.1 \\
\hline 16 & $\mathrm{G}_{16}$ & 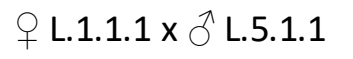 \\
\hline 17 & $\mathrm{G}_{17}$ & q L.1.1.1 x $\precsim$ L.6.1.1 \\
\hline 18 & $\mathrm{G}_{18}$ & q L.2.1.1 x $\overbrace{}^{\Uparrow}$ L.3.1.1 \\
\hline 19 & $\mathrm{G}_{19}$ & q L.2.1.1 x $\overbrace{}^{\lambda}$ L.4.1.1 \\
\hline 20 & $\mathrm{G}_{20}$ & q L.2.1.1 x ठ̂ L.5.1.1 \\
\hline 21 & $\mathrm{G}_{21}$ & q L.2.1.1 x ठ̂ L.6.1.1 \\
\hline 22 & $\mathrm{G}_{22}$ & q L.3.1.1 x ô L.4.1.1 \\
\hline 23 & $\mathrm{G}_{23}$ & q L.3.1.1 x ठ̂ L.5.1.1 \\
\hline 24 & $\mathrm{G}_{24}$ & q L.3.1.1 x ô L.6.1.1 \\
\hline
\end{tabular}

Penelitian ini menggunakan Rancangan Acak Kelompok dengan genotip sebagai perlakuan. Genotip yang digunakan sebanyak 24 genotip hibrida $\left(F_{1}\right)$ masingmasing diulang sebanyak 3 kali, sehingga terdapat 72 unit percobaan. Setiap satuan percobaan terdiri dari 24 tanaman dan sampel pengamatan sebanyak 12 tanaman setiap unit percobaan. Parameter pengamatan dalam penelitian ini adalah umur berbunga (hari setelah tanam), umur panen (hari setelah tanam), panjang buah $(\mathrm{cm})$, diameter buah $(\mathrm{cm})$, tebal daging buah $(\mathrm{cm})$, kadar gula (brix), jumlah biji, bobot buah $(\mathrm{kg})$, dan produksi per hektar (t).

Analisis data menggunakan analisis varians (Anova) yang dilanjutkan dengan uji Duncan pada taraf $5 \%$ dan $1 \%$ apabila terdapat pengaruh yang nyata dalam perlakuan. Nilai heritabilitas dihitung menggunakan taksiran nilai kuadrat tengah pada analisis keragaman Rancangan Acak Kelompok (Tabel 2) (Syukur et al., 2012). Nilai heritabilitas diklasifikasikan menjadi tinggi $\left(h^{2} \geq 0,50\right)$, sedang $\left(0,20 \geq h^{2}>0,50\right)$ dan rendah $\left(h^{2}>0,20\right)$.

Penentuan indeks seleksi pada 24 genotip tanaman melon hibrida $\left(F_{1}\right)$ menggunakan model (Falconer, 1960) sebagai berikut:

$$
\mathrm{I}=\mathrm{b} 1 \mathrm{P} 1+\mathrm{b} 2 \mathrm{P} 2+\mathrm{b} 3 \mathrm{P} 3 .
$$

dimana,

$$
\begin{aligned}
\mathrm{I}= & \text { Nilai seleksi indeks total genotip } \\
\mathrm{B}= & \text { Faktor pembobot masing-masing } \\
& \text { karakter }
\end{aligned}
$$

$P=$ Nilai fenotip yang telah distandarisasi dari suatu karakteryang diamati

Nilai fenotip yang distandarisasi dihitung menggunakan rumus sebagai berikut: 


$$
P=\frac{x-\ddot{X}}{\sigma x}
$$

dimana,

$\mathrm{x}=$ Nilai tengah karakter dari suatu

genotip

Tabel 2. Analisis Varians

\begin{tabular}{lcccc}
\hline $\begin{array}{c}\text { Sumber } \\
\text { Keragaman }\end{array}$ & Derajat Bebas & $\begin{array}{c}\text { Jumlah } \\
\text { Kuadrat }\end{array}$ & $\begin{array}{c}\text { Kuadrat } \\
\text { Tengah }\end{array}$ & Taksiran Kuadrat tengah \\
\hline Genotip & $\mathrm{a}-1$ & $\mathrm{Jkg}$ & KTg & $\sigma^{2} \mathrm{e}+\mathrm{b} \sigma^{2} \mathrm{~g}$ \\
Kelompok & $\mathrm{b}-1$ & $\mathrm{JKk}$ & $\mathrm{KTk}$ & $\sigma^{2} \mathrm{e}+\mathrm{a} \sigma^{2} \mathrm{~g}$ \\
Galat & $(\mathrm{a}-1)(\mathrm{b}-1)$ & $\mathrm{Jke}$ & Kte & $\sigma^{2} \mathrm{e}$ \\
\hline
\end{tabular}

\section{HASIL DAN PEMBAHASAN}

Hasil analisis ragam dari 24 genotip yang diuji menunjukkan perbedaan yang nyata pada karakter umur berbunga, panjang buah, diameter buah, tebal daging buah, kadar gula, jumlah biji, bobot buah dan produksi perhektar. Pada karakter umur panen tidak terdapat perbedaan yang nyata diantara 24 genotip yang diuji (Tabel 3).
$\ddot{X}=$ Nilai tengah karakter dari total keseluruhan genotip

$\Sigma x \quad=$ Simpangan baku

\section{(Tabel 3$)$}

\section{Umur Berbunga, Umur Panen, Panjang Buah, Diameter Buah dan Tebal Daging Buah}

Karakter umur berbunga pada 24 genotip tanaman melon hasil persilangan $\left(F_{1}\right)$ diantara galur-galur tanaman melon menunjukkan perbedaan yang nyata (Tabel 4). Genotip $G_{1}, G_{2}, G_{6}, G_{7}, G_{8}, G_{19}$ dan $G_{23}$ mempunyai umur berbunga terpendek (14 hari), sedangkan $G_{12}$ dan $G_{21}$ mempunyai umur berbunga terpanjang (17 hari). Karakter umur panen tidak berbeda nyata dari 24 genotip yang diuji. Karakter umur panen mempunyai kisaran umur panen dari 61 hari sampai 65 hari.

Tabel 3. Rekapitulasi uji F pada 24 genotip $\mathrm{F}_{1}$ melon

\begin{tabular}{lrrrc}
\hline \multicolumn{1}{c}{ Karakter } & Rata-rata & \multicolumn{1}{c}{ KT } & F hit & KK (\%) \\
\hline Umur Berbunga (HST) & 15,08 & 2,72 & $4,18^{* *}$ & 5,35 \\
Umur Panen (HST) & 63,33 & 4,39 & 1,52 tn & 2,68 \\
Panjang Buah (cm) & 17,96 & 3,94 & $2,96^{*}$ & 6,42 \\
Diameter Buah (cm) & 16,46 & 1,65 & $1,90^{*}$ & 5,67 \\
Tebal Buah (cm) & 4,21 & 0,58 & $2,64^{*}$ & 11,15 \\
Kadar gula (brix) (\%) & 13,11 & 2,39 & $1,96^{*}$ & 8,42 \\
Jumlah Biji & 671,77 & $117.975,21$ & $1,93^{*}$ & 16,85 \\
Bobot Buah (kg) & 2,43 & 0,31 & $7,75^{* *}$ & 8,22 \\
Produksi Per Hektar & & & & \\
(ton/ha) & 49.49 & 156,09 & $8,26^{* *}$ & 8,78 \\
\hline
\end{tabular}

Keterangan : ${ }^{*}=$ berbeda nyata pada taraf $5 \% ;{ }^{* *}=$ berbeda nyata pada taraf $1 \%$; tn = tidak nyata

Karakter panjang buah, diameter buah dan tebal daging berbeda nyata pada 24 genotip yang diuji. Pada karakter panjang buah $\mathrm{G}_{1}$ memiliki panjang buah terpend ek $(16,28 \mathrm{~cm})$ dan $G_{4}$ mempunyai panjang buah terpanjang $(19,91 \mathrm{~cm}) . \quad \mathrm{G}_{21}$ 
mempunyai diameter buah terkecil $(14,87$ $\mathrm{cm}$ ) dan $\mathrm{G}_{16}$ mempunyai diameter buah terbesar $(17,92 \mathrm{~cm})$. Selanjutnya pada karakter tebal daging buah, $\mathrm{G}_{21}$ mempunyai tebal daging buah yang kecil $(3,48 \mathrm{~cm})$ dan $\mathrm{G}_{4}$ mempunyai tebal daging buah yang besar $(4,69 \mathrm{~cm})$.

\section{Kadar Gula, Jumlah Biji, Bobot Buah dan Produksi Perhektar}

Kadar gula pada 24 genotip yang diuji menunjukkan perbedaan yang nyata dengan kisaran 12,08 brix sampai 14,59 brix. Genotip $\mathrm{G}_{21}$ mempunyai kadar gula terendah yaitu 12,08 brix dan $G_{3}$ mempunyai kadar gula tertinggi yautu 14,59 brix. Pada karakter jumlah biji menunjukkan perbedaan yang nyata pada 24 genotip yang diuji di mana $G_{23}$ mempunyai jumlah biji terendah $(470,83)$ dan $\mathrm{G}_{8}$ mempunyai jumlah biji tertinggi $(774,78)$.

Karakter bobot buah dan produksi per hektar menunjukkan perbedaan yang nyata dari 24 genotip yang diuji. Karakter bobot buah mempunyai rentang $2,03 \mathrm{~kg}$ sampai $2,98 \mathrm{~kg}$, di mana $\mathrm{G}_{13}$ mempunyai berat buah terendah dan $\mathrm{G}_{4}$ mempunyai bobot buah tertinggi. Karakter produksi per hektar mempuyai rentang 41,80 ton per hektar sampai 58,90 ton per hektar, di mana $\mathrm{G}_{13}$ mempunyai produksi per hektar terendah dan $\mathrm{G}_{4}$ mempunyai produksi per hektartertinggi.

Tabel 4. Nilai tengah bobot umur berbunga, umur panen, panjang buah, diameter buah, te bal daging buah, kadar gula, jumlah biji, berat buah dan produksi perhektar 24 melon hibrida

\begin{tabular}{|c|c|c|c|c|c|c|c|c|c|}
\hline \multirow{2}{*}{ Genotip } & \multicolumn{9}{|c|}{ Karakter } \\
\hline & UB & UP & PB & DB & TDB & KG & $J B$ & $\mathrm{BB}$ & $\mathrm{PH}$ \\
\hline G1 & $14 \mathrm{a}$ & $64 \mathrm{a}$ & $16,28 \mathrm{a}$ & $16,41 \mathrm{a}-\mathrm{f}$ & $4,17 a b$ & $12,58 \mathrm{ab}$ & $741,45 \mathrm{~cd}$ & $2,11 \mathrm{ab}$ & $43,41 \mathrm{ab}$ \\
\hline G2 & $14 a$ & $64 a$ & $16,72 a-c$ & $15,22 a b$ & $4,05 a b$ & $14,58 \mathrm{c}$ & 592,22 a-d & $2,16 a b$ & $43,42 a b$ \\
\hline G3 & $15 a b$ & $64 \mathrm{a}$ & 17,70 a-d & $16,64 a-f$ & $4,26 a b$ & $14,59 \mathrm{c}$ & 676,67 a-d & $2,25 a b$ & $46,23 a-c$ \\
\hline G4 & $16 \mathrm{~b}$ & $61 \mathrm{a}$ & 19,91 e & $17,56 d-f$ & $4,69 \mathrm{~b}$ & $14,27 \mathrm{bc}$ & 772,44 d & 2,98 b & $58,90 \mathrm{c}$ \\
\hline G5 & $15 a b$ & $62 \mathrm{a}$ & $19,83 \mathrm{e}$ & 17,74 ef & $4,61 \mathrm{~b}$ & 12,93 a-c & 613,00 a-d & $2,93 \mathrm{~b}$ & $58,89 \mathrm{c}$ \\
\hline G6 & $14 \mathrm{a}$ & $64 \mathrm{a}$ & 17,65 a-d & 16,62 a-f & $4,24 a b$ & $12,82 \mathrm{a}-\mathrm{c}$ & $744,33 \mathrm{~cd}$ & $2,53 a b$ & 51,85 a-c \\
\hline G7 & $14 \mathrm{a}$ & $65 a$ & 17,97 a-e & 15,93 a-f & $4,50 a b$ & 12,93 a-c & $750,89 \mathrm{~cd}$ & $2,27 a b$ & 46,63 a-c \\
\hline G8 & $14 \mathrm{a}$ & $64 a$ & 18,80 c-e & $16,43 a-f$ & $4,49 a b$ & $12,88 \mathrm{a}-\mathrm{c}$ & $774,78 \mathrm{~d}$ & $2,40 a b$ & $47,24 a-c$ \\
\hline G9 & $16 \mathrm{~b}$ & $64 \mathrm{a}$ & $16,92 \mathrm{a}-\mathrm{c}$ & 16,20 a-f & $4,22 a b$ & 13,56 a-c & 680,83 a-d & $2,43 a b$ & $48,84 \mathrm{a}-\mathrm{c}$ \\
\hline G10 & $14 \mathrm{a}$ & $62 \mathrm{a}$ & 18,47 b-e & $17,28 \mathrm{c}-\mathrm{f}$ & $4,68 \mathrm{~b}$ & $12,28 \mathrm{ab}$ & 717,39 a-d & $2,80 a b$ & $57,28 \mathrm{bc}$ \\
\hline G11 & $15 a b$ & $63 a$ & $18,41 \mathrm{~b}-\mathrm{e}$ & 16,69 a-f & $4,24 a b$ & 12,89 a $-c$ & 628,00 a-d & $2,62 a b$ & 53,66 a -c \\
\hline G12 & $17 \mathrm{~b}$ & $63 a$ & 17,97 a-e & $17,51 d-f$ & $4,31 a b$ & 12,09 a & 674,11 a-d & $2,36 a b$ & $48,44 a-c$ \\
\hline G13 & $15 a b$ & $65 \mathrm{a}$ & $16,82 \mathrm{a}-\mathrm{c}$ & $15,72 \mathrm{a}-\mathrm{d}$ & $4,12 a b$ & $12,72 \mathrm{a}-\mathrm{c}$ & 727,72 b-d & $2,03 \mathrm{a}$ & 41,80 a \\
\hline G14 & $16 \mathrm{~b}$ & $63 a$ & $16,63 a b$ & 15,90 a-e & $3,90 \mathrm{ab}$ & 13,34 a-c & 610,77 a-d & $2,27 a b$ & $46,63 a-c$ \\
\hline G15 & $16 \mathrm{~b}$ & $64 a$ & 17,78 a-d & $15,27 \mathrm{ab}$ & $3,85 a b$ & 12,69 a-c & 695,39 a-d & $2,47 a b$ & 49,65 a-c \\
\hline G16 & $15 a b$ & $64 a$ & 18,69 b-e & $17,92 \mathrm{f}$ & $4,40 a b$ & 13,22 a-c & 686,78 a-d & $2,63 a b$ & 53,86 a $-c$ \\
\hline G17 & $15 a b$ & $64 \mathrm{a}$ & $18,58 \mathrm{~b}-\mathrm{e}$ & 16,85 a-f & $4,26 a b$ & 13,67 a-c & 516,83 a-c & $2,44 a b$ & $48,04 a-c$ \\
\hline G18 & $15 a b$ & $64 a$ & $19,42 \mathrm{de}$ & $17,05 \mathrm{~b}-\mathrm{f}$ & $4,29 a b$ & 12,89 a $-c$ & $484,00 \mathrm{ab}$ & $2,63 a b$ & 53,86 a $-c$ \\
\hline G19 & $14 \mathrm{a}$ & $61 \mathrm{a}$ & 18,23 a-e & 16,41 a-f & $4,30 a b$ & 14,05 a-c & $774,00 \mathrm{~d}$ & $2,36 a b$ & $48,44 a-c$ \\
\hline G20 & $16 \mathrm{~b}$ & $62 \mathrm{a}$ & 17,63 a-d & 15,80 a-e & $3,88 \mathrm{ab}$ & 13,33 a-c & $605,61 \mathrm{a}-\mathrm{d}$ & $2,17 a b$ & 44,62 a $-c$ \\
\hline G21 & $17 \mathrm{~b}$ & $64 a$ & $16,63 \mathrm{ab}$ & 14,87 a & $3,48 \mathrm{a}$ & $12,08 \mathrm{a}$ & 604,00 a-d & $2,19 a b$ & 45,02 a $-c$ \\
\hline $\mathrm{G} 22$ & $16 \mathrm{~b}$ & 63 a & 17,36 a-c & 15,29 a-c & $3,67 a b$ & $12,39 \mathrm{ab}$ & $757,83 \mathrm{~cd}$ & $2,33 a b$ & 47,83 a-c \\
\hline G23 & $14 \mathrm{a}$ & $63 a$ & $18,31 \mathrm{~b}-\mathrm{e}$ & $17,01 b-f$ & $4,58 a b$ & $12,92 \mathrm{a}-\mathrm{c}$ & 470,83 a & $2,54 a b$ & 52,05 a $-c$ \\
\hline G24 & $15 a b$ & $65 \mathrm{a}$ & $18,37 \mathrm{~b}-\mathrm{e}$ & 16,67 a-f & $3,80 a b$ & 13,00 a-c & $822,67 \mathrm{~d}$ & $2,50 a b$ & 51,25 a $-c$ \\
\hline
\end{tabular}

Keterangan : UBJ = Umur Berbunga (hari setelah tanam); UP = Umur Panen (hari setelah tanam); $\mathrm{PB}=$ Panjang Buah (cm); DB = Diameter Buah (cm); TDB = Tebal Daging Buah (cm); KG = Kadar Gula (brix); JB = Jumlah Biji; BB = Bobot Buah (kg); Produksi Per Hektar (ton); Angka dalam satu kolom diikuti oleh huruf yang sama tidak berbeda nyata pada berdasarkan uji Duncan's pada taraf $5 \%$. 


\section{Heritabilitas}

Heritabilitas merupakan merupakan proporsi besaran ragam genetik terhadap proporsi besaran ragam fenotip, dimana proporsi besaran ragam fenotip merupakan proporsi besaran ragam genetik ditambah dengan proporsi besaran ragam lingkungan (Bekele \& Rao, 2014). Nilai heritabilitas memberikan gambaran apakah suatu karakter dipengaruhi oleh faktor genetik atau faktor lingkungan (nongenetik) (Amzeri, 2009; Sari at al., 2013). Nilai heritabilitas dalam arti luas 24 genotip tanaman melon hibrida $\left(F_{1}\right)$ pada karakterkarakter yang dievaluasi berkisar antara 0,15 - 0,71 (Tabel 5). Pada Gambar 1 menunjukkan bahwa terdapat variasi penampilan 24 genotip tanaman melon hibrida $\left(F_{1}\right)$. Nilai heritabilitas dalam arti luas 24 genotip melon hibrida berdasarkan kriteria nilai heritabilitas memiliki kriteria rendah sampai tinggi. Karakter yang memiliki nilai heritabilitas dalam arti luas rendah adalah umur panen. Karakter yang memiliki kriteria nilai heritabilitas dalam arti luas sedang adalah panjang buah, diameter buah, tebal buah, kadar gula dan jumlah biji, sedangkan kriteria nilai heritabilitas dalam arti luas tinggi terdapat pada karakter umur berbunga, bobot buah dan produksi per hektar. Hasil penelitian Pornsuriya \& Pornsuriya (2009); Sakulphrom et al. (2017) bahwa karakter panjang buah dan diameter buah hasil persilangan melon mempunyai nilai heritabilitas tinggi.

Karakter-karakter yang mempunyai nilai heritabilitas dalam arti luas tinggi menunjukkan bahwa faktor genetik lebih berperan dibandingkan dengan faktor lingkungan (non-genetik) dalam menentukan variasi fenotip (Anshuman et al., 2013). Program pemuliaan pada karakter-karakter yang mempunyai nilai heritabilitas tinggi akan memberikan peluang kemajuan genetik yang tinggi karena karakter yang diamati banyak dikendalikan oleh faktor genetik dan seleksi pada karakteryang mempunyai nilai heritabilitas dalam arti luas tinggi ini bisa dilakukan pada generasi awal (Barmawi, et al., 2013; Olakojo \& Olaoye, 2011).

Tabel 5. Nilai duga komponen ragam dan heritabilitas arti luas pada 9 karakter tanaman melon (Cucumis melo L.) hibrida

\begin{tabular}{lrrrl}
\hline \multicolumn{1}{c}{ Karakter } & $\sigma^{2} \mathrm{e}$ & $\sigma^{2} \mathrm{~g}$ & $\sigma^{2} \mathrm{p}$ & $\mathrm{h}_{\mathrm{bs}}$ \\
\hline Umur Berbunga (HST) & 0,65 & 0,69 & 1,34 & 0,51 (tinggi) \\
Umur Panen (HST) & 2,89 & 0,5 & 3,39 & 0,15 (rendah) \\
Panjang Buah (cm) & 1,33 & 0,87 & 2,2 & 0,40 (sedang) \\
Diameter Buah (cm) & 0,87 & 0,26 & 1,13 & 0,23 (sedang) \\
Tebal Buah (cm) & 0,22 & 0,12 & 0,34 & 0,35 (sedang) \\
Kadar gula (brix) (\%) & 1,22 & 0,39 & 1,61 & 0,24 (sedang) \\
Jumlah Biji & 61278,21 & 18899 & 80177,21 & 0,24 (sedang) \\
Bobot Buah (kg) & 0,04 & 0,09 & 0,13 & 0,69 (tinggi) \\
Produksi Per Hektar (ton/ha) & 18,9 & 45,73 & 64,63 & 0,71 (tinggi) \\
\hline
\end{tabular}

Keterangan: $\sigma^{2}$ e: ragam lingkungan; $\sigma^{2}$ g: ragam genetik; $\sigma^{2} \mathrm{p}$ : ragam fenotipe; $\mathrm{h}^{2}$ bs: heritabilitas artiluas. Kriteria: tinggi $\left(h^{2}{ }_{b s} \geq 0,5\right)$, sedang $\left(0,2<h^{2}{ }_{b s}<0,5\right)$, rendah $\left(h^{2}{ }_{b s} \leq 0,2\right)$ 

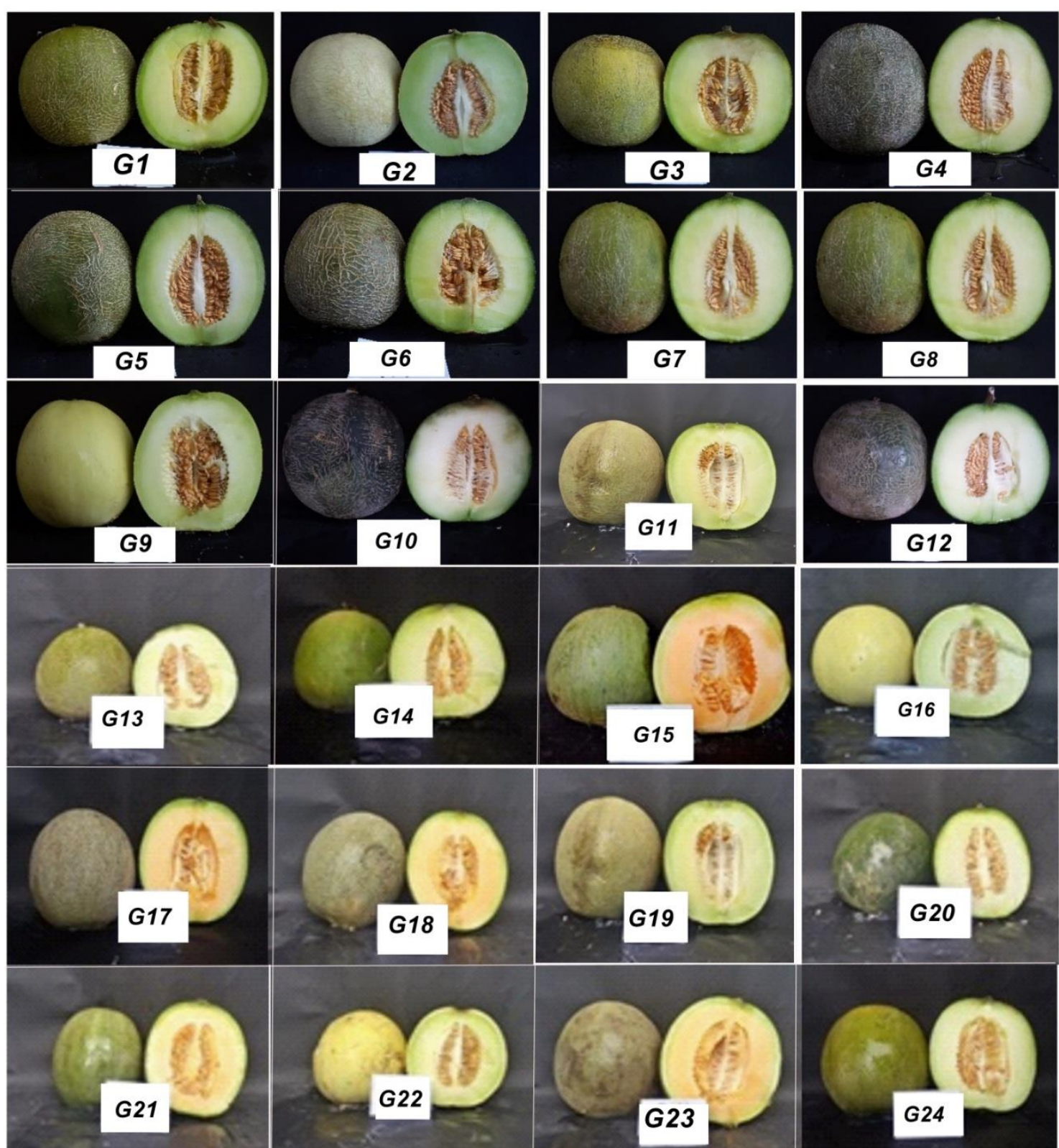

Gambar 1. Buah 24 genotip tanaman melon hibrida $\left(F_{1}\right)$

\section{Seleksi indeks}

Penentuan genotip yang akan dijadikan kandidiat varietas unggul tergantung pada karakter-karakter yang diharapkan oleh pemulia. Seleksi indeks bisa digunakan untuk menentukan genotip terpilih untuk dijadikan varietas unggul, dimana perhitungan seleksi indeks ini didasarkan pada nilai heritabilitas dan nilai ekonomis karakter tersebut (Gazal et al., 2017; Missanjo \& Matsumura, 2017).
Perhitungan seleksi indeks pada penelitian ini didasarkan pada karakter umur berbunga, panjang buah, diameter buah, tebal daging buah, kadar gula, jumlah biji, bobot buah dan produksi perhektar. Delapan karakter yang digunakan dalam seleksi indeks didasarkan pada hasil uji $\mathrm{F}$, di mana karakter umur berbunga, bobot buah dan produksi per hektar berbeda sangat nyata pada taraf $1 \%$. Karakter panjang buah, diameter buah, tebal daging buah, 
kadar gula, dan jumlah biji berbeda nyata

karakter

tersebut

sangat

efisien.

pada taraf $5 \%$, sehingga seleksiterhadap 8

Tabel 6. Seleksi indeks untuk menentukan tanaman melon hibrida terbaik

\begin{tabular}{cccccccccc}
\hline \multirow{2}{*}{ Genotip } & \multicolumn{7}{c}{ Nilai Fenotip yang sudah distandarisasi } & Nilai \\
\cline { 2 - 7 } & $\mathrm{X} 1$ & $\mathrm{X} 2$ & $\mathrm{X} 3$ & $\mathrm{X} 4$ & $\mathrm{X} 5$ & $\mathrm{X} 6$ & $\mathrm{X} 7$ & $\mathrm{X} 8$ & indeks \\
\hline G1 & 2,16 & $-1,60$ & $-0,05$ & $-0,24$ & $-2,12$ & 1,39 & $-4,27$ & $-4,77$ & $-9,49$ \\
G2 & 2,16 & $-1,13$ & $-1,18$ & $-1,20$ & 5,35 & $-1,56$ & $-5,40$ & $-3,85$ & $-6,82$ \\
G3 & 0,16 & $-0,23$ & 0,19 & 0,37 & 5,38 & 0,07 & $-3,60$ & $-1,95$ & 0,41 \\
G4 & $-1,84$ & 1,77 & 1,38 & 3,60 & 4,22 & 1,57 & 7,33 & 6,72 & 24,75 \\
G5 & 0,16 & 1,56 & 1,42 & 3,00 & $-0,65$ & $-1,05$ & 10,00 & 6,60 & 21,03 \\
G6 & 2,16 & $-0,27$ & 0,19 & 0,23 & $-1,16$ & 1,65 & 2,00 & 2,10 & 6,89 \\
G7 & 2,16 & 0,01 & $-0,82$ & 2,18 & $-0,80$ & 1,41 & $-3,20$ & $-2,04$ & $-1,10$ \\
G8 & 2,16 & 0,84 & $-0,04$ & 2,10 & $-1,02$ & 1,54 & $-0,40$ & $-1,61$ & 3,57 \\
G9 & $-1,84$ & $-0,99$ & $-0,35$ & 0,07 & 1,64 & 0,12 & 0,00 & $-0,45$ & $-1,80$ \\
G10 & 2,16 & 0,46 & 1,03 & 3,53 & $-3,32$ & 0,60 & 4,93 & 4,65 & 14,04 \\
G11 & 0,11 & 0,43 & 0,26 & 0,23 & $-0,98$ & $-0,57$ & 2,53 & 2,57 & 4,57 \\
G12 & $-3,84$ & 0,01 & 1,50 & 0,75 & $-5,10$ & 0,05 & $-0,93$ & $-0,63$ & $-8,19$ \\
G13 & 0,16 & $-1,09$ & $-0,78$ & $-0,67$ & $-1,73$ & 1,00 & $-5,33$ & $-4,81$ & $-13,25$ \\
G14 & $-1,84$ & $-1,27$ & $-0,66$ & $-2,33$ & 1,15 & $-0,69$ & $-2,13$ & $-1,97$ & $-9,73$ \\
G15 & $-1,84$ & $-0,17$ & $-1,40$ & $-2,70$ & $-1,85$ & 0,31 & 0,53 & 0,10 & $-7,02$ \\
G16 & 0,16 & 0,70 & 1,54 & 1,43 & 0,40 & 0,33 & 4,00 & 2,61 & 11,16 \\
G17 & 0,16 & 0,56 & 0,39 & 0,37 & 2,24 & $-2,77$ & 0,20 & $-1,02$ & 0,14 \\
G18 & 0,11 & 1,39 & 0,62 & 0,60 & $-0,88$ & $-2,80$ & 4,00 & 2,73 & 5,77 \\
G19 & 2,16 & 0,23 & $-0,05$ & 0,67 & 3,76 & 1,57 & $-1,40$ & $-0,56$ & 6,39 \\
G20 & $-1,84$ & $-0,29$ & $-0,69$ & $-2,48$ & 0,80 & $-1,47$ & $-3,47$ & $-2,95$ & $-12,39$ \\
G21 & $-3,84$ & $-1,11$ & $-1,77$ & $-5,48$ & $-4,12$ & $-1,26$ & $-3,20$ & $-2,63$ & $-23,39$ \\
G22 & $-1,84$ & $-0,57$ & $-1,30$ & $-4,05$ & $-2,88$ & 2,00 & $-1,33$ & $-1,16$ & $-11,14$ \\
G23 & 2,16 & 0,30 & 0,61 & 2,78 & $-0,76$ & $-4,57$ & 1,47 & 1,80 & 3,79 \\
G24 & 0,16 & 0,37 & 0,28 & $-4,10$ & $-0,44$ & 2,74 & 0,93 & 1,08 & 1,03 \\
\hline
\end{tabular}

Keterangan : X1 = umur berbunga; X2 = panjang buah; X3 = diameter buah; $\mathrm{X} 4$ = tebal daging buah; $\mathrm{X} 5=$ kadar gula; X6 = jumlah biji;X7 = berat buah; X8 = produksi per hektar

Tipe ideal yang diharapkan varietas melon yang akan dibentuk adalah varietas melon hibrida yang mempunyai produksi tinggi, kadar gula tinggi dan berumur genjah, sehingga ketiga karakter tersebut menjadi karakter utama dalam kriteria seleksi. Umur berbunga bisa dijadikan indikator umur panen pendek (genjah). Produksi per hektar dan umur panen merupakan parameter yang memiliki nilai ekonomis tinggi. Pemberian bobot didasarkan pada tujuan utama seleksi dan nilai ekonomis masing-masing karakter
(Lunezzo de Oliveira et al., 2014). Menurut Jannah et al. (2018), karakter umur berbunga mempunyai korelasi positif dengan umur panen tanaman, dimana tanaman yang mempunyai umur berbunga pendek akan mempunyai umur panen yang pendek sehingga karakter umur berbunga bisa digunakan sebagai indikator penentuan umur genjah suatu tanaman. Umur berbunga diberi bobot negatif 4 karena karakter ini merupakan tujuan seleksi yaitu menghasilkan tanaman yang mempunyai umur genjah. Produksi per 
hektar dan kadar gula diberi bobot empat karena kedua karakter tersebut merupakan tujuan seleksi, yaitu mendapatkan varietas yang mempunyai produksi tinggi dan kadar gula tinggi, sehingga model perhitungan seleksi indeks adalah:

$I=-4 X 1+2 X 2+2 X 3+3 X 4+4 X 5+X 6+3 X 7+X 8$

Pada Tabel 6 menunjukkan bahwa genotip $G_{4}$ dan $G_{5}$ merupakan hibrida $\left(F_{1}\right)$ yang mempunyai nilai indeks tinggi diantara genotip-genotip yang lain dengan nilai seleksi indeks 24,75 dan 21,03 . Nilai seleksi indeks yang tinggi pada kedua genotip $\mathrm{G}_{4}$ dan $\mathrm{G}_{5}$ dipengaruhi nilai tengah pada karakter umur berbunga yang cenderung pendek masing-masing sebesar 16 hari dan 15 hari, karakter kadar gula masing-masing sebesar $14,27 \%$ dan $12,93 \%$ serta karakter produksi per hektar masingmasing sebesar 58,90 $\mathrm{t} \mathrm{ha}^{-1}$ dan 58,89 t ha $^{-1}$. Berdasarkan nilai seleksi indeks didapatkan 2 calon varietas melon hibrida yaitu genotip $G_{4}$ dan $G_{5}$

\section{SIMPULAN}

Dua puluh empat tanaman melon hibrida $\left(F_{1}\right)$ yang diuji memiliki keragaman pada karakter umur berbunga, panjang buah, diameter buah, tebal daging buah, kadar gula, jumlah biji, bobot buah dan produksi perhektar. Nilai heritabilitas dalam arti luas tanaman melon hibrida $\left(F_{1}\right)$ pada karakter yang dievaluasi berkisar antara 0,15-0,71. Hasil nilai seleksi indeks terboboti menunjukkan bahwa terdapat dua calon varietas tanaman hibrida yang memiliki seleksi indeks tertinggi yaitu $\mathrm{G}_{4}$ dan $G_{5}$.

\section{DAFTAR PUSTAKA}

Amzeri, A. (2015). Dasar-dasar pemuliaan tanaman. UTM-Press Bangkalan, 235.

Amzeri, A. (2009). Penampilan lima kultivar jagung Madura. Agrovigor: Jurnal Agroekoteknologi, 2(1), 23-30.

Anshuman, V., Dixit, N. N., Sharma, S. K., \& Marker, S. (2013). Studies on heritability and genetic advance estimates in maize genotypes. Bioscience Discovery, 4(2), 165-168.

Badan Pusat Statistik (BPS). (2017). Statistik Tanaman Sayuran dan Buah-buahan Semusim Indonesia. Badan Pusat Statistik. Jakarta.

Barmawi, M., Sa'diyah, N., \& Yantama, E. (2013). Kemajuan genetik dan heritabilitas karakter agronomi kedelai (Glycine max [L.] Merrill) generasi F2 persilangan wilis dan Mlg2521. Prosiding Semirata 2013, 1(1).

Bekele, A., \& Rao, T. N. (2014). Estimates of heritability, genetic advance and correlation study for yield and it's attributes in maize (Zea mays L.). Journal of Plant Sciences, 2(1), 1-4. https://doi.org/10.11648/j.jps. 20140201.11

Falconer, D. S. (1960). Introduction to quantitative genetics. Introduction to Quantitative Genetics.

Gazal, A., Nehvi, F. A., Lone, A. A., Dar, Z. A., \& Wani, M. A. (2017). Smith hazel selection index for the improvement of maize inbred lines under water stress conditions. Int. J. Pure App. Biosci, 5(1), 72-81.

Golabadi, M., Golkar, P., \& Eghtedary, A. (2015). Combining ability analysis of fruit yield and morphological traits in greenhouse cucumber (Cucumis sativus L.). Canadian Journal of Plant Science, 95(2), 377-385.

Hartati, R. R. S. R. I., \& Sudarsono, S. 
(2016). Daya Gabung Dan Heterosis Karakter Vegetatif, Generatif, Dan Daya Hasil Jarak Pagar (Jatropha Curcas L.) Menggunakan Analisis Dialel. Jurnal Penelitian Tanaman Industri, 21(1), 9-16.

Ishak, M. A., \& Daryono, B. S. (2018). Kestabilan Karakter Fenotip Melon (Cucumis melo L.'Sun Lady') Hasil Budidaya di Dusun Jamusan, Prambanan, DI Yogyakarta. Prosiding Seminar Nasional Pendidikan Biologi dan Saintek Ke-3.

Jannah, M., Ujianto, L., \& Anugrahwati, D. R. (2018). Koefisien genotipik sifat kuantitatif pada genotipe persilangan blewah dan melon (Cucumis melo L.). CROP AGRO, Jurnal Ilmiah Budidaya, 10(01), 49-55.

Lunezzo de Oliveira, R., Garcia Von Pinho, R., Furtado Ferreira, D., Miranda Pires, L. P., \& Costa Melo, W. M. (2014). Selection indexin the study of adaptability and stability in maize. The Scientific World Journal, 2014.

Missanjo, E., \& Matsumura, J. (2017). Multiple Trait Selection Index for Simultaneous Improvement of Wood Properties and Growth Traits in Pin us kesiya Royle ex Gordon in Malawi. Forests, 8(4), 96.

Olakojo, S. A., \& Olaoye, G. (2011). Correlation and heritability estimates of maize agronomic traits for yield improvement and Striga asiatica (L.) kuntze tolerance. African Journal of Plant Science, 5(6), 365-369.

Olfati, J. A., Samizadeh, H., Rabiei, B., \& Peyvast, G. (2012). Griffing's methods comparison for general and specific combining ability in cucumber. The Scientific World Journal, 2012.

Pornsuriya, P., \& Pornsuriya, P. (2009). Study on genetic effects in fruit shape of oriental pickling melon. Journal of Agricultural Technology, 5(2), 385390.

Sakulphrom, S., Chankaew, S., \& Sanitchon, J. (2017). Genetics Analysis and Heritability of Fruit Characters in Muskmelon (Cucumis melo L.) Using Extreme Parental Differences. AGRIVITA, Journal of Agricultural Science, 4O(1), 1-7.

Sari, L. W., Nugrahaeni, N., Kuswanto, K., \& Basuki, N. (2013). Interaksi Genotipe $X$ Lingkungan Galur-galur Harapan Kedelai (Glycine Max (L)). Jurnal ProduksiTanaman, 1(5).

Syukur, M., Sujiprihati, S., \& Yunianti, R. (2012). Teknik pemuliaan tanaman [Plant breeding technique]. Jakarta, ID: PenebarSwadaya. 